\title{
William Shakespeare, Sonnet I
}

\author{
Renata Maria Parreira Cordeiro
}

Desejo: a toda mor beleza que floresça,

De modo a não murchar do Belo a rosa-flor.

Deflorada, talvez com o tempo feneça,

Então, que a rememore o seu herdeiro amor:

Mas, tu, réu do teu próprio olhar tão cintilante

Nutres o teu brilhar com o teu próprio mel,

Causando privação onde existe o abundante,

Tu és teu próprio algoz; tu, doce e tão cruel!

Tu és, hoje, o mundano e viçoso ornamento

E o arauto da estaçāo das flores a brilhar,

Em teu próprio botão jaz teu contentamento

$E$, mísero e mesquinho, esbanjas ao poupar.

Tu, tem pena do mundo ou serás o glutão,

A comer o que é do mundo, em teu caixão. 
Cadernos de Literatura em Tradução n̊. 1, p. 18-19

On fairest creatures we desire increase, That there by beauty's rose might never die, But as the riper should by time decease, His tender heir might bear his memory: But thou, contracted to thine own bright eyes, Feed's thy light's flame with self-substantial fuel, Making a famine where abundance lies, Thyself thy foe; to thy sweet self too cruel! Thou that art now the world's fresh ornement And only herald to the gaudy spring, Within thine own bud buriest thy content And, tender churl, mak'st waste in niggarding.

Pity the world, or else this glutton be, To eat the world's due, by the grave and thee.

De William Shakespeare, The Sonnets. Londres, Tiger Books International, 1993 